\title{
Sustainability Reporting of Banking Companies in Bangladesh: A Study on Environmental Aspect
}

\section{Md. Jamsedul Islam*}

Department of Tourism \& Hospitality Management, Noakhali Science \& Technology University (NSTU), Noakhali-3814, Bangladesh.

*Correspondence: mji.thm.nstu@gmail.com (Md. Jamsedul Islam, Lecturer, Dept. of Tourism \& Hospitality Management, NSTU, Noakhali, Bangladesh)

\begin{abstract}
:
The purpose of this paper is to know the rules and regulations of sustainability reporting in Bangladesh, the extent of sustainability reporting practice, way of reporting in banking companies of Bangladesh and to assess the disclosure of environmental aspects in sustainability report of the banking companies in Bangladesh for developing a sustainable reporting culture. Global Reporting Initiative (GRI) plays the leading role for developing guidelines in the preparation of sustainability reports. That's why GRI's standard guideline is taken into consideration. The study revealed that sustainability related information in the banking company's annual report was not sufficient enough. Moreover, in most of the cases it was found that the information regarding sustainability reporting did not meet the standard of GRI guidelines. The study sketches the current sustainability reporting trends and practices of the banking industry in Bangladesh. Specifically, the environmental aspect of sustainability reporting is the focus point of this study. Reporting style, report size, items disclosed in the report, environmental awareness activities and future direction related to sustainability reporting practice are also found in this study. It can help different levels of managers, organizations, stakeholders and regulatory authorities to identify issues and areas that they could be focused to formulate future plans for making a sustainable future reporting culture in the banking sector of Bangladesh in order to make the world more sustainable.
\end{abstract}

Keywords: Sustainability reporting, GRI, Environmental aspect, CSR, Bangladesh, and Banking sector.

\section{INTRODUCTION:}

All organizations make positive and negative contributions towards sustainable development through their activities and relationships. So, organizations have a key role to play in achieving a more sustainable economy, environment and society. One of the tools they have available is sustainability reporting, or an organization's practice of reporting publicly on its economic, environmental, and social impacts (Amran and KeatOoi, 2014). Sustainability reporting is a method of reporting as regards to economic, environmental and social performance of an organization (Bowers, 2007). Each of the banks has to publish the reporting following the international standard of GRI, but none except a few are abided by the rules. Sustainability reporting is now a mainstream business practice (CIPFA, 2010). By 2017, 93\% of the world's largest 250 corporations reported on their sustainability performance, according to a KPMG survey (KPMG, 2005; and KPMG, 2008). 
Globally accepted standards, such as the GRI Sustainability Reporting Standards, provide a common language and credible set of disclosures for organizations to communicate about their impacts on the economy, the environment, and society (Report services, 2010). Organizations can combine their use of such instruments to improve the quality and comparability of the information they report publicly. Sustainability reporting provides a broader view of a company's performance than financial disclosure alone.

When used alongside financial reporting, it can reveal value creation across six capitals: financial, manufactured, intellectual, human, natural, social and relationship. Only by capturing the full picture of its value creation can a company thrive, and sustainability reporting is a vital tool in this process. Sustainability reporting can be used to break down silos and build a holistic view of performance. While various reporting frameworks and approaches for disclosing sustainability information are available, for this guidance we refer to the GRI Standards. Reporting on both financial and non-financial information can give companies a broader perspective on risk, and the GRI Standards are a good tool for companies to measure, manage and address the risks. The GRI Standards include references to other widely recognized frameworks, and are designed as a consolidated framework for reporting performance against different codes and norms for sustainability.

Sustainability Reporting is a key tool to help the organization to set goals, measure progress and manage sustainability within the organization. Reporting on the organization's sustainability performance will give internal and external stakeholders a clear idea of its impact and can increase the efficiency and improve the performance. And reporting enables the organization to forward into a successful sustainable future. In a word, a sustainability report is a report published by a company or organization about the economic, environmental and social impacts caused by its everyday activities. A sustainability report also presents the organization's values and governance model, and demonstrates the link between its strategy and its commitment to a sustainable global economy. UniversePG I www.universepg.com
Sustainability reporting may be called in different names such as, a non-financial reporting or triple bottom line reporting (i.e. People, Planet and Profit) or corporate social responsibility (CSR) reporting, and more. Various regulatory authorities of Bangladesh including the central bank of Bangladesh, National board of Revenue (NBR), International Aid agencies, Finance corporations are now getting emphasized on sustainable accounting practices and aspects of sustainable development. Bangladesh bank provides assistance to the commercial banks on CSR related activities. The rising concern for global warming also boosts up the issue to be sustainable in all aspects of business. Banking as a business also went through the opportunities and threats of global warming in Bangladesh. Bangladesh is one of the most vulnerable countries in the world affected by global warming (Pashley, 2015).

This leads the banking sector of Bangladesh to formulate new strategies and products in the recent ages (Khatun, 2016). A recent initiative from the central bank and other regulatory authorities lead the way to be more sustainable and influences the commercial banks to address the issue of sustainable disclosure. Therefore, top managements of Bangladeshi commercial banks would be intended to reinforce their effort of implementing more organized social accountability by engaging stakeholders in their core sustainability activities resulting in adopting a full-fledged GRI guideline in line with developed country practices (Khan et al., 2010). It is important to know the recent scenario of sustainability reporting, especially the environmental aspect in the annual report of the banking companies in Bangladesh in line with the GRI guidelines.

\section{Literature review}

Sustainability reporting is a method of reporting as regards to economic, environmental and social performance of an organization. Each of the banks has to publish the reporting following the international standard of Global Reporting Initiative (GRI), but none except a few are abided by the rules. According to GRI, A sustainability report is a report published by a company or organization about the economic, environmental and social impacts caused by its 
everyday activities. A sustainability report also presents the organization's values and governance model, and demonstrates the link between its strategy and its commitment to a sustainable global economy. Sustainability reporting is a key tool to help an organization in setting goals measuring progress and managing sustainability. Reporting on organization's sustainability performance will give internal and external stakeholders a clear idea of its impact and can increase efficiency and improve performance. Companies may report on sustainability issues in a number of ways such as in their corporate websites, integrated with annual financial reporting or may produce stand-alone sustainability reports. Internal benefits for companies and organizations can include:

Increased understanding of risks and opportunities, Emphasizing the link between financial and nonfinancial performance, Influencing long term management strategy and policy, and business plans, Streamlining processes, reducing costs and improving efficiency, Benchmarking and assessing sustainability performance with respect to laws, norms, codes, performance standards, and voluntary initiatives, Avoiding being implicated in publicized environmental, social and governance failures, Comparing performance internally, and between organizations and sectors, etc (Gazi, 2020). And External benefits of sustainability reporting can include: Mitigating or reversing negative environmental, social and governance impacts, improving reputation and brand loyalty, enabling external stakeholders to understand the organization's true value, and tangible and intangible assets, demonstrating how the organization influences, and is influenced by, expectations about sustainable development etc.

GRI Sustainability Reporting Standards (GRI Standards) help businesses, governments and other organizations understand and communicate the impact of business on critical sustainability issues. Some of the distinctive elements of the GRI Standards Multistakeholder input, a record of use and endorsement, Governmental references and activities, Shared development costs. Sustainable development today appears to have captured the public and political imagination all over the world. The definition that has influenced sustainable development over the past two decades originated from the Brundtland report, which defined the goal of sustainable development to 'meet the needs of the present without compromising the ability of future generations to meet their own needs'. The Global Reporting Initiative (GRI) provides guidance that is applicable to all sectors. It is the world's most widely used standard on sustainability as it enables business, government and individuals to make better decisions based on the disclosures on the organizational sustainable development initiatives and process. Established in 1997, the first version of GRI was published in 2000 and the second generation was unveiled at the world summit on sustainable development in 2002 at Johannesburg. The third versions, known as G3 published in 2006 and were updated to G3.1, expanding guidance on local community aspects, human rights and gender in 2011. Again, in 2010 GRI launched its fourth-generation guideline known as G4. Recently in October 2016, GRI published a new version known as GRI Standards which will be effective after June 2018 (GRI, 2017b).

At the time of the data collection in this study (June 2017), the organization's G4 guidelines were in effect (GRI, 2017c). The GRI-G4 performance disclosure indicators are organized into: Economic: Disclosures on economic value generated and distributed, revenues, and infrastructure investments; Environmental: Disclosures on impact on water, emissions, effluents, waste, biodiversity, and compliance with environmental laws; and Social: Disclosures on human rights, labor practices, benefits, training, education, health, safety, diversity, equal opportunity, procurement practices with regard to anti-corruption and antitrust practice, product responsibility, customer privacy and satisfaction, etc. The concept of sustainability is still very new in Bangladesh. Recently various agencies are creating considerable pressure on companies to act responsibly and be responsible for the impacts they have on social, political and ecological environments. There are expectations from the companies to participate in solving social problems, such as poverty and infrastructure'. With a view to integrate sustainability, Bangladesh Bank (the central bank of Bangladesh) issued guidelines on 'Environmental Risk Management' (ERM) in 2011 which was updated in February 2017 titled as 
'Environmental \& Social Risk Management (ESRM) for Banks and Financial Institutions in Bangladesh' (Milon, 2019). There is no guideline for other sectors except some laws for textile and chemical companies to ensure Effluent Treatment Plant (ETP) for their operations (Hohnen, 2012).

There have been a number of studies examining corporate social reporting in a developing country such as Bangladesh (Belal, 2001; Imam, 2000; Belal and Owen, 2007; Islam and Deegan, 2008). Prior studies (Khan et al., 2010) focused exclusively on the banking sector. Social disclosure practices have evidently directed toward revealing the social disclosures status of banks with capturing a range of stakeholders' perceptions and the impacts of corporate governance elements on banks social reporting. Some studies (Belal, 2001; Imam, 2000) also focused on other companies' practice of economic, social and environmental reporting and most of the studies produced almost similar results. The result reveals that sustainability related disclosures are disclosed by a few numbers of companies in Bangladesh and a synopsis of the studies are described below.

Imam (2000) examined the disclosures practices of 40 listed companies from the Dhaka Stock Exchange on social and environmental aspects. The findings reveal that $25 \%$ of companies made disclosures on community activities and $22.5 \%$ on environmental disclosures whereas only $10 \%$ companies disclose consumer related information (Hackston and Milne, 1996). So, it is evident that companies in Bangladesh disclose information in various aspects but most of the information is not adequate. Only $8.33 \%$ of the Bangladeshi companies address social and environmental issues in their corporate annual report on an average. Thus it is discernible that reporting on corporate website about social and environmental information by the listed companies in Bangladesh is still very low and multinational companies (MNCs) disclose corporate social and environmental information in the website more than local companies.

The study of (Sobhani et al., 2009) reveals that all companies disclosed at least one item related to HR followed by Community involvement by (47\%), consumer (23\%), environment (19\%), and others (18\%). Although 91\% made disclosures in at least one category, the level of environmental and climate change disclosures was very low. 'Disclosures were made in some selected and restricted categories only' (Belal, 2007). According to the study of (Khan, 2015), 'banks commitment towards decent works, labor practices and environmental items were found more than product responsibility and human rights and it has also been evidenced that banks addressed a small number of GRI G3 indicators'. Banks' propensity to follow financial sector specific (FSS) GRI guidelines is very low. Among sixteen (16) FSS and GRI only seven (7) items were disclosed by surveyed banks. That is to say, among the surveyed banks more than half of the financial sector specific disclosures were not reported in their annual reports. Only $41 \%$ of listed financial companies made some kind of CSR disclosure and the average length of disclosures amounted to less than half a page which indicates poor level of disclosure.

(Hohnen, 2012) found that 'organizations in Bangladesh disclose more on community and pay limited attention to workplace/HR disclosure and environment'. The banking and financial companies disclose more on social and environmental issues compared to other sector organizations because of institutional pressure from central banks. They are also showing an emphasis on sustainability disclosure and being accountable to internal and external stakeholders for their action regarding governance, economic, environmental and social aspects including both positive and negative contributions, but still it is not satisfactory. Based on the above analysis of literature, few works have been found on the banking industry but no works have been found which analyze overall sustainable reporting practice by companies in Bangladesh. So, to create awareness for sustainability issues and improve sustainable reporting practice in Bangladesh, this study aims to examine the sustainability reporting practices of top companies in Bangladesh.

\section{Objectives of the study}

The objectives of the study include following:

a) To evaluate the rules \& regulations of sustainability reporting in Bangladesh. 
b) To know the extent of sustainability reporting and way of reporting in banking companies of Bangladesh.

c) To assess the disclosure of environmental aspects in the sustainability report of sample banks.

\section{METHODOLOGY:}

Population: At present sustainability reporting is an important issue for the companies as a result of global sustainable development awareness. The banking companies also have direction and guidelines about this initiative. There are 62 scheduled banks in our country at present. For this study, all the 62 scheduled banks have been selected purposely. This study is basically based on secondary data. And the data source is annual reports and websites of these banks which are enlisted in DSE \& CSE.

Sample: This study has some limitations; all the listed banks are not prepared for sustainability reporting. Among the banks in our country, some banks prepare sustainability reports separately. And some prepare it as part of an annual report. So, we can't take more banks as samples for our study. For this study the sample banks are Bank Asia, Prime Bank and Mutual Trust Bank.

Instruments: Disclosure index; Disclosure index measures the extent to which investors are protected through disclosure of ownership and financial information. The disclosure model for the unweighted disclosure thus measures the total disclosure (TD) score for a company as additive as follows: $\mathrm{TD}=\sum_{i=0}^{n} \quad d i$

Where,

$\mathrm{d}=1$ if the item di is disclosed and 0 if the item di is not disclosed,

$\mathrm{n}=$ number of items.

\section{RESULTS AND DISCUSSION:}

Comparison among report - By analyzing the sustainability reports, annual reports and websites of the sample banks it can be seen which banks prepare separate sustainability reports and which present sustainability analysis in its annual report.
Table 1: Report size and style

\begin{tabular}{|c|c|c|}
\hline $\begin{array}{c}\text { Name of the } \\
\text { banks }\end{array}$ & Report size & $\begin{array}{c}\text { Separated or } \\
\text { not }\end{array}$ \\
\hline Prime bank & $100+$ pages & Separated \\
\hline Bank Asia & $100+$ pages & Separated \\
\hline $\begin{array}{c}\text { Mutual Trust } \\
\text { Bank }\end{array}$ & About 20 pages & $\begin{array}{c}\text { Part of annual } \\
\text { report }\end{array}$ \\
\hline
\end{tabular}

From Table 1, it is seen that Prime Bank and Bank Asia prepare separate sustainability reports. And Mutual Trust Bank prepares sustainability analysis as a part of annual reports. It is also seen that the size of the report of the separate report is different from the rest. The separate report ranges from 1 to 120 pages (approximately). A sustainability analysis section in the annual report ranges from 1 to 25 pages (approximately).

Disclosed items - Sustainability report consists of four aspects. Environmental aspect is one of them. In the sustainability report or sustainability analysis section in the annual report some environmental issues are disclosed. By analyzing the sustainability reports, annual reports and websites of the sample banks it can be seen which items and how many items they disclose in their sustainability report and annual report. Almost every sample bank discloses some familiar items and some unfamiliar items related to the environment in the sustainability report or sustainability analysis section in the annual report.

Table 2: Disclosure of environmental issues by the sample bank.

\begin{tabular}{|l|c|c|c|}
\hline Items & Prime bank & Bank Asia & MTB \\
\hline $\begin{array}{l}\text { Total disclosure } \\
\text { items }\end{array}$ & 26 & 26 & 26 \\
\hline $\begin{array}{l}\text { Total items } \\
\text { disclosed }\end{array}$ & 20 & 18 & 17 \\
\hline $\begin{array}{l}\text { Average } \\
\text { disclosure }\end{array}$ & 0.76923 & 0.69230 & 0.65384 \\
\hline $\begin{array}{l}\text { Disclosure } \\
\text { index }\end{array}$ & 0.70512 & & \\
\hline
\end{tabular}

From Table 2, it is seen that the total no. of disclosed items in the sustainability report or sustainability analysis section in the annual report among the sample 
banks is 26. And Prime Bank disclosed 20 items, Bank Asia disclosed 18 items and MTB disclosed 17 items respectively in their report. And average disclosed items in respect of total disclosed items in each sample bank are 0.76923, 0.69230, and 0.65384 for Prime Bank, Bank Asia and MTB respectively. And the disclosure index is 0.70512 .

\section{Similarities and dissimilarities in programs -}

Environmental issues are an important issue in every aspect of our country and society. Banking companies are also having some guidelines about environmental issues. They have taken some programs, events, and projects related to the environmental aspect. By analyzing the sustainability reports, annual reports and websites of the sample banks it can be understood about similarities and dissimilarities in projects, events and various programs among the sample banks.

Table 3: Disclosure of similar and dissimilar programs/events by sample banks.

\begin{tabular}{|l|c|c|c|}
\hline \multicolumn{1}{|c|}{ Items } & Prime bank & Bank Asia & MTB \\
\hline $\begin{array}{l}\text { Total disclosure } \\
\text { items }\end{array}$ & 18 & 18 & 18 \\
\hline $\begin{array}{l}\text { Total items } \\
\text { disclosed }\end{array}$ & 12 & 7 & 7 \\
\hline $\begin{array}{l}\text { Average } \\
\text { disclosure }\end{array}$ & 0.66667 & 0.38889 & 0.38889 \\
\hline Disclosure index & & 0.48148 & \\
\hline
\end{tabular}

From Table 3, it is seen that the total no. of programs, events, projects taken and disclosed by the sample banks are 18. And the no. of programs disclosed are 12 in Prime Bank, 7 in Bank Asia, and 7 in MTB respectively. The average disclosure is 0.66667 in Prime Bank, 0.38889 in Bank Asia, and 0.38889 in MTB respectively. And the disclosure index is 0.48148 .

\section{Environmental awareness of sample banks -} Environmental sustainability concerns an organization's impact on living and non-living natural systems, including ecosystems, land, air, and water. Environmental sustainability issues cover performance related to input (e.g., material, energy, water) and output (e.g., emissions, effluents, waste). Additionally, they cover performance related to biodiversity, environmental compliance, and other relevant information such as environmental expenditure and the impacts of products and services (GRI, 2016; Jony et al., 2019). The economic sustainability disclosure of the listed banks in the latest annual reports and corporate websites have been presented under two sub- headings, namely, disclosure concerning energy consumption and savings, and disclosure pertaining to the natural environment.

There is growing evidence suggesting that climate change risks have important implications for financial stability, although the analysis of the complexity of the potential risks to the financial sector is still at an early stage. Banks loan exposure to elevate environmental risk. Banks have to emphasize to assess the environmental risk before lending as the bank's loan exposure raises environmental risk. We all are aware of the fact that the change in climate has a direct impact on biodiversity, agriculture, forestry, dry land, water resources and human health. To safeguard the planet and its ecosystem from the adverse effect of environmental degradation caused by rising carbon emission, encroachment of rivers, improper disposal of industrial waste, medical \& household waste, deforestation, loss of open space etc. Prime Bank in line with global norms has already introduced Green Banking and sustainable practices. Being a leading commercial bank in

Financial market of Bangladesh, Prime Bank Limited can influence economy, society, people and the environment-both directly and indirectly through our stakeholders. Prime Bank is striving for excellence to create Social, Environmental and Economic Benefits and publishing Sustainability Report since 2013. The Bank has taken initiative to prepare Sustainability Report uniformly by following the new Guidelines named "GRI Standards" in 2016 to communicate to its stakeholders about its impacts on the economy, the environment, and /or society. In order to protect the environment, the Bank is spreading its wings by introducing both in-house \& external green activities towards supporting Green Economy. Energy efficient in-house Management works through reduction of energy \& resource consumption such as reduction of paper-use, maximum use of day light and environment 
friendly business activities by financing renewable energy. Bank's Green banking activities is day-by-day flourishing towards creating a "Greener" future for the welfare of the society. For a sustainable economy Prime Bank Limited plays crucial role in financing environment friendly projects led by green banking which believes in social responsibility.

Bank Asia always believes in growing in a responsible manner maintaining eco friendly environment by playing a major role to mitigate Environmental risks which is essential for our survival. Since its inception, Bank Asia has been committed towards Sustainable Development that makes environmentally, economically and socially responsible. As a Bank, we play an intermediary role between economic development and conservation of the environment. Our Green Banking activities are on multidimensional areas which include both in house Green activities towards supporting Green Economy. The Bank's working environment encourages usage of e-mails, relying on online instructions for communication, using natural daylight and extensive usage of energy savings bulbs. These steps show the Bank's efforts towards encountering in house environment manage-ment as part of supporting green banking. Our Green Banking Policy Guidelines and Green Office Guide have been circulated to all our employees for creating awareness on Green Banking activities \& providing instructions about conserving energy, water, saving paper, etc.

Bank Asia developed its own Environmental Policies which proves our commitment to the Environment for a sustainable future. We have unified our sustainable operations under the "Green Banking Unit" equipped with permanent employees. Besides this, Bank Asia has also introduced a new department in early 2017 named Sustainable Finance Department the same in alignment with Bangladesh Bank with its proficient Sustainable Finance Committee to monitor Sustainable Banking and Sustainable Finance. MTB also has initiatives - As per instruction of Bangladesh Bank and as approved by the MTB Board of Directors at its meeting held on December 28, 2016, Sustainable Finance Unit has been formed in MTB. From the beginning of its journey, the unit is working hard to ensure due diligence in environmental and social issues in every investment of MTB.
The Executive Committee of the Board of Directors, at its 98th meeting, held on December 04, 2017, approved "Environmental and Social Risk Management (ERSM) Policy and Procedure of MTB2017'. This policy and procedure is a modification/ amendment of our existing "Environmental Risk Management (ERM) Guidelines". Unlike the ERM guidelines issued in 2011, this policy is more dynamic and comprehensive in nature and accommodates social risks management issues in addition to covering latest improvements in environmental risk management. This paper is based on the "Guidelines on Environmental and Social Risk Management (ESRM) for banks and financial institutions in Bangladesh" issued by Bangladesh Bank (BB) vide their SFD Circular No. 02 dated February 08, 2017.

\section{CONCLUSION:}

It is observed that the analysis states that the banks are showing an emphasis on sustainability disclosure day by day in an effort to measure, disclose and be accountable to internal and external stakeholders in terms of governance, economic, environmental and social aspects. This report intends to touch upon environmental aspects for the purpose of sustainable development and recognize its benefits businesses acknowledge the necessity of sustainable reporting day by day. The objectives of the study are to analyze the condition of Bangladeshi banks regarding sustainability reporting practices and disclosing environmental issues in sustainability reports. The study reveals that, only a few banks are disclosing the sustainability related information in their annual report only but that was not sufficient enough. For ensuring good governance and better transparency, all the regulators as well as the civil society should have to come forward to develop a sustainable reporting culture. This will ultimately make our beloved world more sustainable, improve governance snags and increase the efficiency and effectiveness of the banking sector of Bangladesh. In future there is ample scope to conduct further research on sustainability reporting in various sector and other aspects of sustainability reporting; such as, sustainability reporting practices in RMG industries, sustainability reporting in power generation companies, sustainability reporting in fertilizer manufacturing 
companies, GRI guidelines and DSE guidelines related to sustainability reporting, extent to which GRI guidelines and standards are met, and social aspect of sustainability reporting etc. actually these are few example of future research scope in this field.

\section{ACKNOWLEDGEMENT:}

Thanks to all those persons, who have assisted us, providing us co-operation to the successful research.

\section{CONFLICT OF INTERESTS:}

The author declares that they have no competing interests with respect to the research.

\section{REFERECES:}

1. Amran A., and KeatOoi, S. (2014). Sustainability reporting: meeting stakeholder demands. Strategic Direction, 30(7), 38-41. https://doi.org/10.1108/SD-03-2014-0035

2. Belal A.R. (2001). A study of corporate social disclosures in Bangladesh. Managerial Auditing Journal, 16(5), 274-289. https://doi.org/10.1108/02686900110392922

3. Belal A.R., Owen, D.L. (2007). The views of corporate managers on the current state of, and future prospects for, social reporting in Bangladesh e an engagement-based study. Accounting, Auditing and Accountability Journal, 20(3), 472-494. https://doi.org/10.1108/09513570710748599

4. Belal A.R. (2007). Absence of Corporate Social Reporting in Bangladesh: a Research Note. From Research Workshop. Aston Business School, 1-43. http://publications.aston.ac.uk/id/eprint/199 26/1/CPA Belal and Cooper 2011.pdf

5. Bowers T. (2010). From image to economic value: a genre analysis of sustainability reporting. Corporate Communications: An International Journal, 15(3), 249-262. https://doi.org/10.1108/13563281011068113

6. CIPFA, (2010). Sustainability Reporting. A Public Services Perspective: The Chartered Institute of Public Finances \& Accountancy.

7. Gazi MAI. (2020). Islamic perspective of leadership in management; foundation, traits and principles, Int. J. Manag. Account. 2(1), 1-9. https://doi.org/10.34104/ijma.020.0109

8. Global Reporting Initiative (GRI), (2016). G4 Sustainability Reporting Guidelines. Retrieved 13 January, 2017.

https://www.globalreporting.org/information/g 4/Pages/default.aspx

9. GRI, (2017b). About Sustainability Reporting. Retrieved 13 January, 2017.

https://www.globalreporting.org/information/s ustainability-reporting/Pages/default.aspx

10. GRI, (2017c). G3 Guidelines. Retrieved 1 February 2017.

https://www.globalreporting.org/information/g 4/G3andG3-1/g3-guidelines/Pages/default. aspx

11. Hackston, D., and Milne, M. (1996). Some determinants of social and environmental disclosures in New Zealand companies. Accounting, Auditing and Account-ability Journal, 9(1), 77-108. http://dx.doi.org/10.1108/095135796101099 $\underline{87}$

12. Hohnen P. (2012). The Future of Sustainability Reporting (Vol. EEDP Program Paper: 2012/02). London: Chatham House.

13. Imam S. (2000). Corporate social performance reporting in Bangladesh. Managerial Auditing Journal, 15(3), 133-141.

14. Islam M.A., and Deegan, C. (2008). Motivations for an organization within a developing country to report social responsibility information. Accounting, Auditing and Accountability Journal, 21(6), 850-874.

15. Jony MTI, Alam MJ, and Rana MS. (2019). Customers' satisfaction of service quality: a study on the customers of DBBL at different areas of Mymensingh district. Can. J. Bus. Inf. Stud., 1(5), 10-16. https://doi.org/10.34104/cjbis.019.01016

16. Khan M. H.-U.-Z., Islam, D. M. A., \& Ahmed, K. (2010). Corporate Sustainability Reporting of Major Commercial Banks in line with GRI: Bangladesh Evidence. Paper presented at the 6th Asia Pacific 
Interdisciplinary Research on Accounting (APIRA) Conference, Sydney, Australia.

17. Khan M. T. A. (2015). Sustainability Reporting Under Global Reporting Initiative (GRI). The cost and management, $\mathbf{4 3}(05), 04-$ 17.

18. Khatun F. (2016). Banking sector for sustainable growth, Supplements. The Daily Star.

http://www.thedailystar.net/supplements/25thanniversary-special-part-5/banking-sectorsustainable-growth-212689

19. KPMG, (2005). KPMG International Survey of Corporate Responsibility Reporting (pp. 155). Amsterdam: University of Amsterdam and KPMG Global Sustainability Services.

20. KPMG, (2008). International Survey on Corporate Sustainability Reporting. KPMG Global Sustainability Services, Amstelveen.
21. Milon M., (2019). Present scenario of human resource management (HRM) practices in the life insurance companies: Bangladesh perspective. Can. J. Bus. Inf. Stud., 1(6), 1727. https://doi.org/10.34104/cjbis.019.01727

22. Pashley A. (2015). Climate change to wipe $2 \%$ off Bangladesh GDP by 2050. Retrieved 16 January, 2017. http://www.climatechangenews.com/2015/09/ 25/climate-change-to-wipe-2-off-bangladeshgdp-by-2050/

23. Report services, (2010). GRI Sustainability Reporting Statistics, Publication Year, 2010.

24. Sobhani F.A., Amran, A., Zainuddin, Y. (2009). Revisiting the practices of corporate social and environmental disclosure in Bangladesh. Corporate Social Responsibility and Environmental Management 16, 167e183. https://doi.org/10.1002/csr.193

\section{APPENDICS:}

\section{(i) Disclosure of environmental issues:}

\begin{tabular}{|l|l|l|l|}
\hline \multicolumn{1}{|c|}{ ITEMS } & PRIME BANK & BANK ASIA & MTB \\
\hline Initiative for sustainable financing & 1 & 1 & 1 \\
\hline Financing to ensure safe working environment for the worker & 1 & 0 & 0 \\
\hline Bio-Gas plant program & 1 & 0 & 0 \\
\hline Vermi-compost program & 1 & 0 & 0 \\
\hline Effluent treatment plant (ETP) & 1 & 1 & 1 \\
\hline Financing in environment friendly brick kiln & 1 & 0 & 0 \\
\hline Agriculture and rural credit & 1 & 1 & 1 \\
\hline Introduction of agriculture loan product & 1 & 0 & 1 \\
\hline Environmental responsibility & 1 & 1 & 1 \\
\hline Green banking governance & 1 & 1 & 1 \\
\hline Internal management of environmental resources & 1 & 1 & 0 \\
\hline Paper consumption & 1 & 1 & 1 \\
\hline Paper reduction framework & 1 & 1 & 1 \\
\hline Material topics and topic specific disclosure & 1 & 0 & 0 \\
\hline Energy consumption within the organization (Direct and indirect) & 1 & 1 & 1 \\
\hline Water consumption & 1 & 1 & 1 \\
\hline Waste management & 1 & 1 & 0 \\
\hline Greenhouse gas emission & 0 & 1 & 1 \\
\hline Solar plant powered branches and homes & 0 & 1 & 1 \\
\hline Financing renewable energy and carbon offset project & 0 & 1 & 0 \\
\hline Reducing energy and resource consumption & 1 & 1 & 1 \\
\hline
\end{tabular}

UniversePG I www.universepg.com 


\begin{tabular}{|l|l|l|l|}
\hline Initiative to reduce the bank's adverse impact on environment & 1 & 1 & 1 \\
\hline Reducing carbon footprint & 0 & 1 & 0 \\
\hline Online banking & 1 & 1 & 1 \\
\hline SME financing & 0 & 0 & 1 \\
\hline Land and forest ecological footprint & 0 & 0 & 1 \\
\hline
\end{tabular}

(ii) Disclosure of programs/events:

\begin{tabular}{|l|l|l|l|}
\hline PROGRAMS/ EVENTS/ PROJECTS & $\begin{array}{c}\text { PRIME } \\
\text { BANK }\end{array}$ & $\begin{array}{c}\text { BANK } \\
\text { ASIA }\end{array}$ & \begin{tabular}{c} 
MTB \\
\hline Automation in banking system
\end{tabular} \\
\hline Bio gas production technology programs & 1 & 1 & 1 \\
\hline Effluent Treatment Plant (ETP) & 1 & 1 & 0 \\
\hline Hybrid Hoffman Brick Field (Environment friendly technology) & 1 & 1 & 1 \\
\hline Solar home system & 1 & 1 & 1 \\
\hline Solar irrigation plant & 0 & 1 & 1 \\
\hline Green event: Earth day & 0 & 0 & 1 \\
\hline Free Altitude subscription for one year & 1 & 0 & 0 \\
\hline Pot Bonsais to customers & 1 & 0 & 0 \\
\hline Environmental \& Social (E\&S) Risk Management Capacity Building & 1 & 0 & 0 \\
\hline Environmental \&Social Risk \&Opportunities Management (ESROM 2.0) & 1 & 0 & 0 \\
\hline In-house Training on "E\&S Risk Management” & 1 & 0 & 0 \\
\hline $\begin{array}{l}\text { Workshop on "Environmental \& Social Safeguard and Compliance Reporting” by } \\
\text { Bangladesh Bank }\end{array}$ & 1 & 0 & 0 \\
\hline E\&S Training organized by IFC \& FI Consult & 1 & 0 & 0 \\
\hline Saving CO2 emission & 1 & 0 & 0 \\
\hline Promoting Rural entrepreneurship & 0 & 1 & 0 \\
\hline Production of Burnable Oil from Waste Tire by the Process of Pyrolysis & 0 & 1 & 0 \\
\hline SME financing for woman entrepreneur & 0 & 0 & 1 \\
\hline
\end{tabular}

Citation: Islam MJ. (2020). Sustainability reporting of banking companies in Bangladesh: a study on environmental aspect, Can. J. Bus. Inf. Stud., 2(2), 35-44. https://doi.org/10.34104/cjbis.020.035044 (C) 